\title{
Islam and Christianity in the Middle Volga Region in the Second Half of the XVI-XVIII Century
}

\author{
Dina A. Mustafina ${ }^{1}$ \\ ${ }^{1}$ Kazan (Volga Region) Federal University, Kazan, Russia \\ Correspondence: Dina A. Mustafina, Kazan (Volga Region) Federal University, 420008, Kazan, Kremlyovskaya \\ Street 18, Russia. E-mail: maktub29@yandex.ru
}

Received: June 2, 2015 Accepted: June 15, 2015 Online Published: June 29, 2015

doi:10.5539/jsd.v8n5p54 URL: http://dx.doi.org/10.5539/jsd.v8n5p54

\begin{abstract}
The relevance of the problem under investigation related to the religious policy is caused by the need of studying the historical experience of relations between the Orthodox state and the other faiths, crowned with tolerance and legitimization of Islam and the need to develop both an optimal model of church-state relations and ethnic and religious policy, not only in the medieval period, but in the context of the challenges of modernity and politicization of religion. Article examines the religious policy of the Russian state in relation to the non-Orthodox religions, especially Islam, in the process of entering a multi-confessional and multi-ethnic territory of the former Kazan khanate in the orbit of the functioning of the Russian state in the second half of the XVI-XVIII centuries. Its aim is to highlight the evolution of the political line of aversion to religious tolerance caused by the resistance of the non-Russian peoples of the baptism. The paper concluded that the possibility of allocating the six milestones Christianization of the non-Russian peoples of the Middle Volga region as part of the emerging empire in the XVI-XVIII centuries. It is noted that in general, despite the limitation of the non-Russian population owners' rights, infringement of socio-economic rights of the Yasak majority and a pressure on Muslim clerics, this policy proved to be ineffective against Muslims. It is noted that the relaxation of Christianization was due to social movements, among which a rebellion. It is emphasized that awareness of the need to review the relationship of Islam and a peaceful coexistence between the two faiths, to some extent led to their subsequent convergence. The materials of the article have value for understanding the formation of cultural, historical and national identity, adding principles of interaction with other cultures, able to lead to a mutually beneficial dialogue, for research on the history of both Russia and the peoples of the Volga-Ural region. Also the materials of the article may be used in general and special courses of Russian history and the history of religion.
\end{abstract}

Keywords: Confession, Islam, Orthodoxy, religious policies, the imposition of Christianity, religious tolerance, the Middle Volga, the Russian state

\section{Introduction}

\subsection{The Object and the Purpose of the Study}

Relations between the two faiths - Islam and Orthodox Christianity in the Middle Volga in the second half of the XVI-XVII centuries have become the object of study in this paper, without which representation of the history of the integration of the former Kazan khanate in the political and social system of the Russian state cannot recreated. The aim of our study is to examine the evolution of the religious policy of the government towards Muslims from extreme aversion to religious tolerance.

\subsection{Making Consolidating Idea}

Achieving political supremacy over the fragments of the Golden Horde in the XVI century could be possible only united around a certain idea. It was the idea of the superiority of Orthodoxy over Islam, the idea of God's chosen people of Muscovite state and its ruler (Pelenski, 1974). Grand Princes of Moscow sought to emphasize and demonstrate this by implementing forced conversions of the Zolotaya Orda nobility, primarily chingisieds, thereby achieving a reduction of possible contenders to the throne in post-orda states, the Muslim population was deprived of a leader-banner that is likely to be destabilizing and lead the fight against the political onslaught of the Moscow State before the fall of Kazan and the struggle for the restoration of the statehood after the conquest of Kazan and Astrakhan (Belyakov, 2011). 


\subsection{The Necessity of Studying the Relationship between Orthodoxy and Islam}

In the second half of the XVI century. Muslim yurts Kazan was the first to be included into the Orthodox state, and this was the beginning of the formation of the Empire, in which orthodox ideology is to hold firmly a dominant position. The Church will be one of political institutions involved in the decision-wide problems (Kappeler, 1982). Understanding of the problem from the standpoint of civilizational development, shows that the attack on Islam and paganism in the conquered region was expected and inevitable, for the formation of a coherent and sustainable social organism is largely dependent on its ideological unity. But the policy of planting of Christianity in the Middle Volga region proved to be ineffective against Muslims, to provide massive resistance to baptism. This fact played an important role in the gradual awareness of the need for tolerance towards Islam, to achieve a peaceful coexistence between the two religions. Tolerance was accompanied by a certain degree of convergence between the faiths (Islaev, 2005). Studying the experience of interfaith and intercultural harmony and dialogue inherent in Russia, calls for investigation of the history of relations between Christianity and Islam, and to determine the causes behind the formation and approval of a tolerant policy towards the non-Orthodox confessions. This problem is now attracting both domestic and foreign researchers (Korshunova, 2002; Frank, 1994; Geraci, Khodarkovsky, 2001; Martin, 2001; Romaniello, 2003; Romaniello, 2007; Zemtsova, 2007).

\section{Methodological Framework}

\subsection{Leading Approach to the Research}

The methodological basis of the article was a systematic approach in conjunction with the principle of historicism. General scientific systematic approach involves the use of socio-historical, general science and interdisciplinary methods: problem-chronological, historical and comparative, retrospective, and others for transmission and analysis of historical material.

\subsection{Methods of the Dialectical Understanding of the Problem}

The principle of historicism involves consideration of the peculiarities of relations between Islam and Orthodox Christianity in the Middle Volga in the second half of the XVI-XVIII centuries. Taking into account the specific historical conditions. The evolution of the political line of the Russian State in respect of the non-Orthodox population in this period, reasons for the low efficiency of the policy of promoting Orthodoxy against the Muslim population, factors contributing to the formation of a tolerant attitude towards Islam, performed in chronological order. Essentially-content analysis of legislative materials and reflecting the degree of their use in practice the documentary materials made it possible to highlight relations between the two ideologies of the Middle Ages, who were at a disadvantage (because Orthodoxy is the state religion), six qualitatively different stages. The development of relations between Islam and Orthodoxy was studied in the space-time aspect. Systematic approach to the problem made it possible to identify causal relationships in addition and the transition from confrontation to tolerance of Orthodoxy against heterodox beliefs. The object of the study was considered as an organic whole, with all the successive changes of its essence. Also we used the principle of objectivity which involved the coverage and comprehensive study of historical phenomena in all their complexity, versatility and inconsistency.

\section{Results}

\subsection{The Ideologization of Supreme Authority in the Moscow State}

The integration of the former Khanate of Kazan to the Russian state was not easy. Military confrontation between the two heirs Jochi Ulus, culminating in the victory of the Muscovite state, could not lead to the creation of a homogeneous political organism. The main obstacle to this is an ideological, philosophical difference that existed between the two countries being once part of the same empire. The conquest of Constantinople by the Ottoman Turkey turned the Moscow State into the only bulwark of orthodoxy and led the ideology of sovereignty, to the desire to expand the circle of adherents of this branch of Christianity. With increasing their power in Moscow grand princes (rulers) have resorted to baptism, not only as a means of neutralizing political figures, but also as a tool for the formation of their social support (Belyakov, 2011). "Kazan War" of 1552-1557 that broke out immediately after the fall of the capital of the Khanate of Kazan showed that the strengthening of royal power in the conquered region is possible only under the condition of establishing of such forms of governance fundamentally different from the traditional exarchate, marginalization, or the weakening of the traditional beliefs, diluting of the concentration of the Muslim population by means of the "education" through Christianity and change in social status. It is for this purpose, Bishops Department was established in Kazan as one of the institutions of the impact on society, intensive construction in the region of monasteries and churches 
(Romanello, 2003; Werth, 2003).

Archbishop of actual second branch in the province, was given unprecedented right to release criminals from punishment provided that they make baptism (Mustafina, 2011). It was very thoughtful agitation and propaganda trick designed to emphasize the humane spirit of Orthodoxy. No accident record in the annals shows that perceived Kazan know what is happening (the construction of a fortress on Sviyaga phenomenon pagan saints, trapping the queen Suyumbika with his son) as a punishment for their sins (Adrianov, 1914). However, there is no reason to believe that the Orthodox Church has started mass baptism immediately after the fall of Kazan. Especially that some of the top of society itself communicates his own future with the new government and has taken steps to ensure that meet the requirements of the changed political situation. It seems that the winners in destroying everything that symbolized the old power, its institutions, but in this case we should talk about the traditional "law of war", and not a well thought-out political line, which affected the entire territory of the Middle Volga. Order and consistency in implementation of policies will be characterized by the Christianization of government measures much later - in the XVIII century.

\subsection{The First Activities of the Tsarist Government in the Conquered Region}

Undoubtedly, the baptism of the captive king of Kazan and nobles, distributed in Novgorod prisons and monasteries in order to achieve their "voluntary" will on change of faith has been undertaken in the second half of the XVI century. in order to make informed political supremacy, won by Moscow ruler, a protector and carrier of Orthodox ideology, God's representative on earth. This category of baptized received livelihood in revenue from the territories, local villas etc. (some other mixed kinds of livelihood often were foreseen) in areas spatially separated by a considerable distance from their homes in order to avoid contact with the population of their native country. Were hardly voluntary decision on the acceptance of baptism of the population of the former khanate, caught in the maelstrom of the first months after the conquest of Kazan and punitive actions during the "War of Kazan" in 1552-1557.

But among the newly- baptized of the second half of XVI-XVII centuries there were many representatives of the feudal circles of Volga peoples who decided to take this step in order to preserve in existence or to obtain a new material content, the desire to become "his" for a new government, from a desire to preserve their social status. They linked their future with the service (military and administrative) in the Middle Volga and even managed to show themselves, assisting, promoting and participating in military actions of the tsarist government, have proved to be a real loyalty (Nogmanov, 2006). They were given the courts in the fortified parts (fortresses) of Kazan and Sviyazhsk. According to the first scribe of the surviving descriptions, undertaken in the 60s. of the XVI century. throughout the Middle Volga region, a part of the community musketeers and urban population of Kazan and Sviyazhsk identified 28 people with Tatar names, and among court owners only in Kazan - the names of the 26 newly- baptized and 11 Tatars (Frantsuzova, 2002; Nogmanov, 2006). The number of neophytes was negligible. Thus, at the end of XVI. converts the Kazan district and suburbs were placed in one of the settlements of Kazan. Therefore, to talk about rampant baptism of even citizens of Kazan in the first decade after the fall of the city is not entirely correct. This fact is confirmed by the presence of Tatar street in Sviyazhsk - the city, initially arisen as a Russian fortress which became the center for the spread of Christianity (Frantsuzova, 2002), as well as the existence of persons with Turkic names, even 94 years after the fall of Kazan (Nogmanov, 2006).

It should be noted that the initiative of the construction of Christian places of worship, came not only from governments but also from the clergy and the various layers of the Orthodox population. For example, in the period of 15 years that have elapsed since the capture of Kazan 31 constructions intended for the administration of the Orthodox rites appeared in the city. Of these, only 8 were built on government money, while the rest were built at the expense of the monasteries (4), the governor and servicemen (2), on the initiative of priests urban population (17) (Nogmanov, 2006). Activity in this case is due to not only the desire to spread Christianity, but also the need to strengthen the faith of the Orthodox, who, being in a confessional different environment, fell under the spell unknown culture that was fraught with the danger of erosion of the number of adherents of Christianity. Besides neophytes taking Orthodoxy exclusively from material considerations, did not fulfill its rites and continued their traditional way of life of a Muslim. Furthermore to Islam in 1593 cemented his shaky position: in Kazan were re-built mosque. This caused extreme resentment of a newly appointed Metropolitan Hermogenes in bringing of all newly-baptized from a county to the village of Kazan, the destruction of mosques and punishment of apostates from newly-baptized and careless Christians (Khodarkovsky, 1996). As you can see, in the late XVI century the priority was not the spread of Christianity, and retention in the newly- baptized in a new faith and avoiding conversion to Islam Christians (Nogmanov, 2002). The government is not solved to exert direct pressure on the traditional beliefs, but indirectly, resettling Russian servicemen in the region, encouraging the peasant and monastic colonization, making it difficult for Islam to exist. 


\subsection{Restriction of Possessory Rights of the Non Orthodox Feudals}

The era of "the Troubles" with its civil war, the Polish-Swedish intervention, imposture, etc. dulled the sharpness in the relationship of Orthodoxy and Islam, and created the conditions for strengthening the material well-being of the Tatar landlords. By the Boyar verdict in 1615 possessions available to servicemen were recognized as legitimate, regardless of the methods of acquisition (Nosov, 1986). Domestic and foreign policy interests of the government in 20-40-th caused quite a flexible policy towards people of other faiths. The authorities do not intervene in the internal affairs of Muslim and pagan communities. Her attitude to the various social strata of the population of non-Orthodox variety was different. She continued the tradition of forcing a change of faith of those who remained in the former faith and able to become a figure of gravity and centrifugal forces of chingisieds and Mirza Edige descendants for the sake of social stability. At the same time steps were taken to limit as well as to protect the rights of the Tatar feudal landlords, at that treating them on a case-by-case basis to take into account, first and foremost, military expediency. Property status of Tatars were different, the economy of it (at the beginning of the XVII century made up more than $62 \%$, in the middle of the century - $79 \%$ ) was small, the amount of land ranged from 2 to 5 tithes, there was no dependent population. Labor shortages for farming led to the impoverishment and erosion servitors' layer, forced to pledge, sell, rent or farm out the land to Yasak people and Russian landlords, move to Yasak and ignore the need of service. The decree of 1622 prohibiting unbaptized Tatars to settle Orthodox pashennih kholops (peasants who plow) in their yards, to own Orthodox servicemen, but allowing to own captive Latvians seriously complicated the situation (the same decree, addressed to foreigners was adopted in 1627/28) (Nosov, 1986). The government of Tsar Mikhail Fedorovich thereby made the first open statement on the limitation of the feudal Muslim owners' rights. Infringement of the rights on religious lines was the result of the burst of religious fanaticism and intolerance coming from Metropolitan Filaret, who had returned from and the Polish exile and ousted his son Michael from the throne. The decree was carried out badly, but, nevertheless, was a serious test for the part of Tatars, for such a restriction of the rights of ownership of the dependent population actually supplanted the known part of the feudal-Muslims from the ranks of the privileged class servitor.

In 20-40-ies the struggle for land- the source of economic wealth and social status- intensified, in the land disputes power held a more affluent side. However, the state still needed Tatars soldier who in the 30-ies made up $20 \%$ of the Russian troops. Therefore, in cases of an increased frequency of land transactions the decree was adopted in 1635, which prohibited the Russian landlords to buy, take a mortgage and hire the local Tatar lands (Nosov, 1986). But the decree was circumvented by producing hidden sale - swaps. The state needed Muslim Tatars, for attempts to penetrate the markets of eastern countries closed to non-Muslims. Hence the continued support and the provision of trade privileges was given to the Tatars of Kazan settlements. In the first half of the XVII century. Islam steadily maintained its positions. It is witnessed by Council Code of 1649 on the consolidation of the Orthodox as the official state religion and the inclusion of norms providing punishment as a penalty-burning for introducing the Russian people to Islam.

\subsection{Establishing the General Line of the Government Policy}

In the second half of the XVII century despite of all the contradictions and zigzags, the general line of policy, which had a clearly anti-Muslim character was determined. The tip of this course was aimed at reducing the tenure of the unbaptized servitors. The non-servicemen faced with a choice: to accept the new conditions of existence, replacing faith or lose their social status, to abandon their careers and lose their possessions. The 80-th became culminating in this respect when there was another surge in religious fanaticism and just as quickly was abandoned. On May 16, 1681 a decree on the confiscation of possessions Tatar feudal lords for allegedly forcing their feudal-dependent people to Islam was adopted. On May 24, 1681 a decree addressed to Romanov murzas and baptized Tatars was issued. According to the decree the land was transferred to those murzas and Tatars who refused to be baptized.. At this the latter ought to be sent to Uglich, and Romanov Tatars were laid all the costs for their support. When the government began to actively implement rules decree in life, they met resistance and opposition from the Tatars: flow of petitions from landowners in the 1681-1682 period increased, a powerful revolt of Tatars in the Middle Volga and Urals broke out. In May 1682 it was allowed to return half of the selected estates to their former owners. In July 1682 the authorities ordered to return and the second half of the confiscated possessions. As a result the non-Russian service class appeared to be split, and was immersed into the struggle for land. The rapid rejection of the original course was dictated also by foreign policy interests of the government of Sophia Alekseevna: increased need for soldiers. In general, in the years of her reign there was a softening in policy towards Muslims: it was forbidden to land tributaries to Russian landlords, abandoned estates should be given only murzas and Tatars, the issues of inheritance of estates and estates of unbaptized owners (baptized could inherit only unclaimed land of unbaptized), were rated. It was forbidden to give the land to the 
Tatar landlords estate in other cities. However, in practice these standards were slightly observed.

\subsection{Toughening the Government's Policy}

The government's policy towards Islam remained complex and heterogeneous in the XVIII century (Shkerdina, 2009). Government policy in relation to non-Orthodox became tougher. The active attack on the position of Islam was carried out in three areas: 1) the restriction of the rights of the owners' tops the non-Russian population; 2) the desire to take control of Muslim clerics (Ahuns and mullahs); 3) the provision of tangible indulgences to baptized Yasach. On the basis of decrees of 1713 and 1715 servitors and Tatars who have not accepted Christianity within six months were deprived of their Orthodox peasants with their land allotments. However, the nominal decree in 1726 baptized, and in 1729 the resolution of the Supreme Privy Council unbaptized Tatars were told to return the plots under the condition that they are not passed on to new owners, or credited to the palace fund. And in 1730 there was a decree that the confiscated land was returned only to those baptized. Furthermore, the decree of 1718 servicemen nobleman, Tatars, Chuvash Mordva and were attributed to the Admiralty and began to perform the ships duty.

Thus another blow to the Tatar feudal lords was struck, from which they have not recovered. A homogeneous ethnic-estate group of a taxpaying population - Lashman appeared. The adoption of the decree of the Senate on non-christening of Tatars and others adherent of another faith against their will in 1719 shows that forced conversions continued to be the case (Speransky, 1830 a). However, other methods have been used and, in particular, by providing a variety of benefits: in 1720 newly-christened were released from the various and fee taxes for three years and in 1722 - from the recruiting service. Missionary work became more active, churches were built, schools were opened, neophytes were given cash rewards. Yet the government's steps against non-Orthodox, taken from 1701 to 1740 can not still be regarded as a measure aimed at a mass baptism. Preservation of Islam had to be put up with. But this time was a "running start" before the apotheosis of a zero tolerance policy towards Islam, observed in the 1741-1761 period.

\subsection{Missionary Activity in the Region}

Activation of missionary activity established back in 1731 by Novokreschenskii office, empowerment of administration in respect of the non-Russian peoples, as expressed in the relocation and resettlement of newly-christened in places of compact residence of the Russian population, the construction of churches, detection and control of cases of harassment of newly-christened, destruction and ban the construction of mosques, prosecution for conversion to Islam, the control over marriage, relaying of taxes of newly-christened on those who rejected christening, - all this was to destroy the influence of Islam in the Middle Volga region. Mass baptism was successful, but the majority of apostates were Chuvash, Mordva, Mari and other peoples of the region. According to the information of different sources the share of Muslim Tatars in the total mass of newly-christened was from 2.4 to $7.2 \%$ (Nogmanov, 2002).

Tough Cristianization policy implemented as an infringement of socio-economic rights of non-Orthodox population, and the forcible baptism led to social explosions, among which the revolt of the Tatar population under the leadership of Mullah Batyrsha in 1755, supported by the Bashkirs and other nations was the most ambitious. A direct consequence of people's movements has been the gradual softening of the government's course. It manifested itself, in particular, in the liberation of unbaptized Tatars from the obligation to allocate recruits of newly-christened, in the resolution of construction of mosques, letting newly-christened resettle from the Muslim villages if their share does not exceed one tenth of the people and a number of others. Positive changes in religious policy were reflected in the decree of 1764 and in the original documents adopted by the Legislative Commission of 1767. The office of Novokreschenskii cases was abolished, material compensation for the change of faith was canceled, abolished the obligation to pay taxes and supply of recruits for the baptized. Persecution of other faiths was declared inadmissible.

The 1773 decree "On the tolerance of all faiths and the prohibition of bishops to join the cases relating to the heterodox confessions, and to building upon the law of prayer houses, providing all this secular superiors" was the last chord of a change in government policy in relation to non-Russian Orthodox population (Speransky, $1830 \mathrm{~b}$ ). The line on the tolerance of Islam has become irreversible.

\section{Discussion}

Studying of the religious policy of the Russian government of the second half of the 16th-18th centuries shows that Islam which turned into persecuted religion after the liquidation of the Kazan Khanat eventually was never eliminated from the social practices. Moreover, it was attractive for ordinary Orthodox people. The tsarist government understood it well and wanted the newly converted people to stay separate. But this requirement was 
not always fulfilled. In the sources there are references to the joint business and trade activities between Muslims and Christians. The secular authorities treated it calmly but representatives of the church were completely against it as they considered it to be the threat to Christianity. So it was in 1593 and in 1737 (Mustafina, 2010). We think that the explanation for this should be sought in the gradual formation of differences between the interests of church and state. Abandonment of economic coercion and justification of non-forcible Christianization were dictated by the realization of priority of the confessional stability in a multi-ethnic Russian Empire. Gradually Islam turned to be bearable religion. In this connection it is worthwhile mentioning that it was the Empress CatherineII who changed the attitude towards all confessions in Russian State. She was called by the people "aby-patsha" (granny-empress). The evolution of the relations between Orthodoxy and Islam led to the subsequent inter ethnic and intercultural dialogue, which stood the test of time.

\section{Conclusion}

The relationship of Islam and Orthodoxy in the Russian state in the second half of the XVI-XVIII centuries unfolded in terms of recognition of Orthodoxy as an official ideology. The state policy towards Islam was contradictory and ambiguous. Overprotection of one of the denominations in the poly-confessional and multi-ethnic society and ill-conceived actions in the spiritual and religious spheres led to a secret and open resistance and caused a change in a government policy. The largest concentration of the protest against the patrimonial approach to the solving problem of Christianization of non-Russian peoples of the Volga-Ural region, against the attack on feudal rights of military men who did not want to be baptized and violent methods of consistent missionary policy in the XVIII century, carried the revolts 1661-1664, 1681-1683, 1705-1711, 1735-1740, 1755-1756, as well as the peasant war led by S.T. Razin (1670-1671), and under the leadership of E.I. Pugachev (1773-1775). Understanding government policy and expounding the reasons of the rebel's moods and conflicts caused by strengthening of administrative and organizational activities of the secular and spiritual branches of the Christianization of "infidels" was carried out by one of the Muslim priests (Mullah), known under the name Batyrsha, who became the ideological inspirer and organizer of the uprising in 1755-1756 years. The religious policy of the government against Muslims and people of other faiths for two and a half centuries underwent major changes and evolved from intolerance, having reached its zenith during the reign of Peter I, for tolerance under Catherine II. Existing sources on this issue in the evolution of relations between the two major religions in the XVI-XVIII centuries let us distinguish six stages: 1) the second half of the XVI century-1610 years; 2) 1620 - 1640 years; 3) 1650 - 1700 years; 4) 1701-1740 years; 5) 1741-1761 years; 6) 1762-1796 years. It is likely that in the future the outlined systematization will undergo changes and be detailed. In this case, the issues related to the attitude towards the Muslim clergy, reflecting both the desire of the authorities to take them under state control, and the scholar mullahs' response to it, will be explored thoroughly. It seems that further studies should reveal the sources and reasons for which the government decided to focus its attention on Muslim priests and the effectiveness of this policy. Aspiration to unify the peoples of Russia spiritually due to a desire to avoid the formation of centrifugal forces, objectively contributed to a more rapid integration of the peoples in the Russian socio-cultural space, but at the same time it has brought society to a civilizational split, softened by tolerant attitude of the government of Catherine II and which was completely overcome during the Soviet era.

\section{Recommendations}

Materials of the article are valuable for understanding the formation of cultural, historical and national identity, adding principles of interaction with other cultures, which are able to lead to a mutually beneficial dialogue. Also they can be used for research on the history of Russia, the history of the peoples of the Volga-Ural region, as well as in general and special courses of Russian history and the history of religion, in creating textbooks on Russian history of XVIII century, the history of the Tatar and other peoples of the Volga-Urals region.

\section{Acknowledgments}

The work is performed according to the Russian Government Program of Competitive Growth of Kazan Federal University.

\section{References}

Adrianov, C. A. (Ed.). (1914). Complete Collection of Russian Chronicles, published by the Archeological Commission (Vol. 20, second half, Lviv chronicle, part two). St. Petersburg: Imperial Archeographic Commission.

Belyakov, A. B. (2011). The Chinggisids of the XV-XVII century in Russia: prosopographical research. Ryazan.

Frank, A. J. (1994). Islamic regional identity in imperial Russia: Tatar and Bashkir historiography in 18 and 19-th centuries. Indiana University. 
Frantsuzova, E. B. (Comp.). (2002). Sviyazhsk. In M. Ya. Volkov, \& Z. V. Dmitrieva (Eds.), Russia's cities of the XVI century: cadastres' material (pp. 337-390). Moscow.

Geraci, R. P., \& Khodarkovsky, M. (2001). Of The Conversion of Non-Christians in Early Modern Russia. In $O f$ Religion and Empire: Missions, Conversion, and Tolerance in Tsarist Russia (pp. 115-143). Ithaca: Cornell University Press.

Islaev, F. G. (2005). The religious policy of the Russian state and its implementation in the Volga-Ural region: the XVIII century (Unpublished doctoral dissertation). The Kazan State University named after V.I. Ulyanov-Lenin. Kazan.

Kappeler, A. (1982). RußlandsersteNationalitäten. Das Zarenreich und die Mittleren Wolgavom 16 bis 19. Jahrhundert, Köln-Wien.

Khodarkovsky, M. (1996). "Not by Word Alone”: Missionary Policies and Religious Conversion in Early Modern Russia. Comparative Studies in Society and History, 38(2), 267-293. http://dx.doi.org/10.1017/S0010417500020260

Korshunova, O. N. (2002). The processes of social and cultural interaction between ethnic communities in the Volga and Ural regions in the XVIII-XIX centuries.as the problem of the historical and political study (Unpublished doctoral dissertation). The Kazan State University named after V.I. Ulyanov-Lenin. Kazan.

Martin, J. (2001). Multiethnicity in Muscovy: A Consideration of Christian and Muslim Tatars in the 1550s-1580s. Journal of Early Modern History, 5, 1-23. http://dx.doi.org/10.1163/157006501X00014

Mustafina, D. A. (2010). Donesenie arkhiepiskopa Sil'vestra (k voprosu o poverennykh v torgovykh delakh XVIII v.) The report of the Archbishop Sylvester (on the issue of attorneys in commercial matters XVIII.) In I. A. Gilyazov (Ed.) Aktual'nye problemy istorii i kul'tury tatarskogo naroda Current problems in the history and culture of the Tatar people (pp. 278-286). Kazan

Mustafina, D. A. (Ed.). (2011). A set of written sources on the history of Sviyazhsky Region. (\#1, The sources on the history of Sviyazhsk Region of the second half of the XVI century). Kazan.

Nogmanov, A. I. (2002). Tatars of the Middle Volga and Ural regions in the Russian legislation of the second half of the XVI-XVIII centuries: Essays on the history of the legislative policy of the second half of the XVI-XVIII centuries. Kazan.

Nogmanov, A. I. (Ed.). (2006). Kazan and Kazan district's cadastres of the 1565-1568 years. Kazan.

Nosov, N. E. (Ed.). (1986). Legislative acts of the Russian state of the second half of the XVI- the first half of the XVII centur (\# 78, p. 85, \# 119, p. 113, \# 224, pp. 165-166).

Pelenski, J. (1974). Russia and Kazan: Conquest and Imperial Ideology (1438-1560s). The Hague, Mouton, pp. 205-210.

Romaniello, M. (2003). Absolutism and Empire: Governance on Russia's Early-Modern Frontier. $\mathrm{Ph}$.D.dissertation, Ohio State University, USA.

Romaniello, M. (2007). Mission Delayed: the Russian Orthodox Church after the Conquest of Kazan. Church History, 76(3), 511-540.

Shkerdina, O. N. (2009). Interaction of towns and villages in the process of dissemination and consolidation of Christianity on the territory of the Volga region in the XVIII century. In A. G. Ivanov (Ed.), Problems of studying the relationship of the town and the village of the Middle Volga region: Proceedings of the II All-Russian (X Interregional) Conference of the historians and agrarians of the Middle Volga region (pp. 43-49). Yoshkar-Ola, Mari-El: the Mari state university.

Speransky, M. M. (Ed.). (1830a). Complete Collection of Laws of the Russian Empire. First collection (Vol. 5, \#3410, pp. 726-727). St. Petersburg.

Speransky, M. M. (Ed.). (1830b). Complete Collection of Laws of the Russian Empire. First collection (Vol. 19, \#13996, pp. 775-776). St. Petersburg.

Werth, P. (2003). Coercion and Conversion: Violence and the Mass Baptism of the Volga Peoples, 1740-55. Kritika: Explorations in Russian and Eurasion History, 4(3), 543-569. http://dx.doi.org/10.1353/kri.2003.0048

Zemtsova, O. (2007). Educational factor in the process of Christianization of Non-Russian Peoples of the Middle-Volga Region in the second half of the 19-th century. Budapest, Hungary. 


\section{Copyrights}

Copyright for this article is retained by the author(s), with first publication rights granted to the journal.

This is an open-access article distributed under the terms and conditions of the Creative Commons Attribution license (http://creativecommons.org/licenses/by/3.0/). 